\section{Historical-Scientific Schools Of Management Of Culture And Art}

Toychieva Sayyora Suyarkulovna,

Doctor Of Philosophy, Professor, Uzbek State Institute Of Arts And Culture, Uzbekistan

\begin{abstract}
G OPEN ACCESS
The American Journal of Social Science And Education Innovations JULY 2020

Page No.: 62-70

Volume-II Issue-VII

PUBLISHED: 30 JULY 2020 www.usajournalshub.com/inde x.php/tajssei

Copyright: Original content from this work may be used under the terms of the Creative Commons Attribution 4.0 licence.
\end{abstract}

\title{
Abstract
}

This article deals with the historical and scientific schools of culture and art administration. The first past of mankind, the first material and spiritual, cultural centers were formed in the East and prepared the ground for the further development of mankind [1.239].

The cradle of enlightenment in the ancient East. There is a philosophy of common features and values that unite it as a whole. Since Uzbekistan is an integral part of the East, The ingenuity of the peoples of the East, the desire to make the necessary decisions in the current situation, the purpose of human life - to be an example in labor, to avoid evil, it can be seen that spending a once-in-a-lifetime life on good deeds has become a criterion for life.

Keywords: Institution, scientific institution, creative exam, organization and management of activities of Eastern thinkers, academy, management, faculty, department, specialist, culture and art, bachelor, master, college, school.

\section{Introduction}

There are about seven billion people on earth, and only more than two hundred of them 
have their own state. The antiquity of the state system is a characteristic feature of the Uzbek people. The well-known figures who created the system of formation, development, improvement and practice of the system of governance testify to the ancient history of this nation. In the effective work of the administration, the enlightenment reforms of the heads of state have certainly made a worthy contribution to the enlightenment of culture and the arts, and this has always been recognized. The unrest, which threatens the peace and tranquility of the country, and the bias in the country's domestic and foreign policies, in turn, have shaped the attitudes of prominent scholars, clerics, poets, and writers about leaders.

\section{The Main Findings And Results}

The services of scientific intellectuals and well-known talents are also emphasized in the administration. For example, the activities of the brave commander Jaloliddin Manguberdi and Sheikh Najmiddin Kubro, a contemporary of the Temurid prince and minister Alisher Navoi.

A special place is given to the unique scientific views of Aristotle, a world-renowned encyclopedic thinker who made a great contribution to the development of science, and the research of Abū Nașr Fārābì (873-950), one of the founders of the Greek school of wisdom. The first recognition of governance, the scholar writes, is "the ability to make effective use of them ( from subordinates) by giving everyone a worthy task, depending on their talents and skills". According to the thinker, analysis and comparison, constant observation are the main tasks of management, the manager. This is the reason why the scholar acknowledged that "good deeds can be attained only if the nurturing and purification of the Spirit continues" [2. 280].

As you read the works of the thinker, the three criteria that form the basis and core of the development of management are: you will witness the activities of a virtuous society (i.e. a society of knowledge and enlightenment), a just system (i.e. a system based on justice and fairness) and a just leader (a leader who advocates only righteousness and justice).

"Man cannot create everything he needs on his own, he needs the services of people of different professions to find them. Other people will be in the same situation. People will 
need to unite in community and community to meet their needs and find perfection. In this team, each person learns professions according to their nature, talents and abilities, and strives for perfection in their art (craft) every day. Therefore, people living in different places (belonging to different nationalities and different religions) unite into different societies.These societies are some complete and some incomplete.

Full communities are of three types: large community, medium community, and small community. A great society is a community of all the places on earth and the people who live there. The average society is a nation. A small community is an association of residents of a city. Incomplete communities are rural, neighborhood, and family communities. The family is the smallest community. The neighborhood and the village belong to the city, and the village community serves the townspeople (to deliver the product). The neighborhood is part of the city, the street is part of the neighborhood. The city is a part of the country. Nations are a world society made up of different countries [ 2 . 238].

Fārābi fully substantiates the role of culture in the development of society in his books like "A city of noble people", "Kitabli madanital-fozila vaal-madanatalmubaddalavaal-madanatazzola" (A book about the city of the virtuous, the ignorant, the wicked, the changed and the lost), (Kitab mabodioroual-madanatal-fozila" A book about the basics of the views of the people of Fozil), "Kitabas-siyosatal-Madaniya va yurafubima bodiyal-mavjudot" ("A book on the policy of cities, it is known as the beginning of existence"), "Kalomfial-millatal fikhal-madaniy" ("A word about the right of people and cities to govern"), "Kitab fial-ijtimootal- madaniya" ("Book about City Meetings"). The essence of the works is a common description of the scholar's concepts such as "madaniyat", "al-madaniya", "al-madanat", "al-madaniy" with the life of society, human relations and qualities [2.480].

A cultural society and a cultural city (or country) is such that everyone from the population of that country is free in the profession, everyone is equal, there is no difference between people, everyone is engaged in the profession they want or choose. People will be truly free. There will be no sultan (i.e. king) who interferes with the peace and freedom of the people. Between them there are various good habits, pleasures. There 
will be no absolute leader or chief of staff elected by them. They will be the most noble, tested, worthy of guidance, raised among men. Such leaders therefore liberate their constituents completely, protecting them from an external enemy. Such leaders treat everyone equally, even putting the interests of all above their own interests, sacrificing their personal interests for the benefit of the common good, and spares no effort and wealth for the benefit of the people, "scholar said [2. 284].

It should be noted that in Fārābì's views, the role of cultural knowledge in society is a priority, the unifying cultural science of all the good qualities inherent in human beings, the priority of which is to unite society only with cultural knowledge.

Another oriental sage known as Qutadğu Bilig, or knowledge that leads to happiness, is Yusuf Khas Hajib (born about 1020 in Bolosug - death unknown). This work, dedicated to the ruler of the Karakhanid kingdom, Tavgach Boghrakhan, was written in 1069. The enlightened intellectuals of the people describe the poets in this work as "word-writers", the events of the eleventh century, the way of life of the people at that time, treatment, and in this play, which shows his relationship to good and evil, he describes the poets as "sharper than a sword" and "thinner than a string of memories." He compares the people of the pen to the divers who went into the sea and brought out diamonds, rubies, and pearls. Judging by this criterion, Qutadğu Bilig is a unique treasure of such pearls" [3. 5].

The highest criterion of all wise mother wisdom is the value of man, the attitude towards man, and the scholar goes on to say:

Man is the owner of all beings, society, the wealth and support of man is intelligence, and the basis of society is knowledge, intelligence. A peaceful and prosperous life is tasted only if it is a criterion of human intellect, compromise and attitude, and there will be progress, perfection, and the skill of a leader who can see progress and perfection in a just and far-sighted way. A society based on justice and prosperity will thrive, thrive, and provide for domestic and foreign policy. There are many examples in history that any wise and enterprising leader has acted on the basis of well-respected and respected intellectuals - representatives of culture, religion, literature and art.

The views of the scholar are evident in his respect for science and enlightenment, 
the leader's use of every word in its place, the culture of treatment is extremely high, the result of harsh treatment is a crisis, the people and justice are valued and only then respect is inevitable.

It is no secret that the leader's adherence to word and deed, that is, the unity of word and deed, the inevitable fulfillment of the promised task in a timely and voluntary manner, will inevitably increase his prestige in the eyes of his employees. In this regard, the unconditional fulfillment of the principle of "Good intentions, good words, good deeds" written in the "Avesto" has a great impact on both the leader and the effectiveness of the work. If a leader does not keep his word, backs away from what he says, and does not follow what he says, it will certainly have a very significant impact on both his reputation and the development of the organization.

The scholar reminds him again and again that a self-respecting leader should be extremely just, knowledgeable, intelligent, virtuous and virtuous, and that he should only increase his followers and make them productive.

Another shining example of the spiritual heritage of mankind is the image of the thinker Mind (Ogdulmish), who imagines the principle of Eastern rule, the leader's reasoning, attitude skills, and foresight convince the reader of how much he should be superior to other officials, politicians, advisers, intellectuals, and ambassadors.

The thinker is the intelligence, patience, compromise suggests that initiative should be the leader's primary goal. If justice and fairness are the primary goal of the leader, if the power of the state in that society is known in terms of justice, the thinker describes the development and progress of that society, the ability of a just society to provide a country of deeply observant, independent-minded, intelligent leaders whose decisions are carried out without discussion, all principles based only on the criteria of perseverance. The scientist tried to show in concrete examples that these qualities are the main goal not only of the leader, but also of every conscious citizen and intellectual of the society, and it is an honor to live, work and create in that society.

Indeed, the thinker also compared these four qualities to human life, pointing out that each of the four qualities is a period of human life consisting of four parts. For example, justice is youth, the state is youth, intelligence is mediocrity, patience is old age [4.6]. 
Another thinker is Nizamulmulk, one of the leaders of the Seljuk state, who had his own worldview and teachings in history and administration. Nizamulmulk was born in 1017 in Tus, Iran. His real name was Abu Ali al-Hasan ibn Ali ibn Ishaqat-Tusi and he was the title of Nizamulmulku. It is known as "Nizamul-mulk", ie the charter of property. In the palace of the Seljuk ruler Alp Arslansaray, and later in the service of his son, 17-yearold Malikshah (1072 - 1092), while serving as a minister, he managed almost all the affairs of the state in accordance with the instructions of the rulers, and gained special respect both among the courtiers and the citizens. As a minister, Nizamulmulk waged a fierce struggle against the supporters of partisanship and separatism (among tribes, clans, nobles) in every country, he drew the attention of the members of society to the fact that the power of the state lies in unity, in concerted action, and in turn achieved this through peaceful, compromise. In 1091 he completed the book "Siyosatnoma" ("Siyarul-muluk") as an interpretation of the generalization of his activities in the field of continuous observation, drawing the necessary conclusions from his observations, various differences and conflicts.

The play focuses on problems in governance and a number of principles related to their solutions, the families of rulers, the activities of judges, close awareness of the situation of soldiers and citizens, taxes, zakat, state secret affairs (e.g. espionage). This work draws the necessary conclusions and conclusions from the events that take place in the process of human management, such as the fact that a person faces this or that problem every day, which one solves the problem in the right way, which one makes a mistake, which one needs the help of an official. as if it were a work that would be a lesson to future leaders.

The value of the "Siyosatnoma" is that the politician and reformer Nizamulmulk as a minister, as a manager, compromises and reconciles the leaders of the upper and lower echelons, fair leadership, discipline first, the ability to use responsibility and skill, honesty, integrity, piety, strong will and believing that working with faith is a prerequisite for the development and prosperity of a country. Nizamulmulk is killed by a hired assassin on his way to Baghdad [5].

Often when it comes to just rulers, examples are given from legends about them 
among the people. Just as everything has its own norm, equality of balances, the "Siyasatnoma" contains valuable ideas about the justice of the ruler, kindness and generosity, generosity and entrepreneurship, the equal use of kindness and anger. If we imagine that too much trust and kindness leads to the excess of the employee, too much anger leads to the frustration of the managers of the employees, we can be sure that this is true.

In this historical work, Nizamulmulk has clearly proved that the correct assessment of conflicts and disagreements, the balance of justice can be ensured only if the balance is balanced.

Of course, the great achievement of the "Siyosatnoma" is that vigilance, vigilance, the ability to draw the right conclusions from emergencies depends on the skill of the manager.

In addition to the well-known scholar F.Ravshanov's views on national leadership, it should be noted the following:

\section{Vigilance and entrepreneurship of the leader in matters of} management:

Proper organization of work in the management process;

The management system is the correct and appropriate selection of managers and employees for each position;

Management system and civil relations;

The evolution of leadership and external relations;

The state, the results of the changes that lead to or contradict the goals and ideas of the country, and the role of leadership;

Analysis of negative vices or positive qualities in society;

Solving the problems of the state and the national economy

Social order, ensuring the effective implementation of regulations

The need to manage the formation, development and alternatives to common goals of ideological relations arising from various social, economic, political and spiritual reasons is detailed in the work "Siyosatnoma" [5. 100-153] 
The field of culture and art has always been in need of special recognition and care. The Nizamulmulk's "Siyosatnoma" on the special protection of creative people and the creation of adequate conditions for them is like a textbook. That is why the Constitution considers the protection and care of individuals as one of the important tasks of the state, the leadership:

\begin{tabular}{|l|l|}
\hline$\bullet$ & $\begin{array}{l}\text { Temporary or retired military leaders with a high reputation } \\
\text { among the people; }\end{array}$ \\
\hline$\bullet$ & $\begin{array}{l}\text { Retired officials who have previously held public office; } \\
\text { people of science and virtue (poets, Sufis, clerics, famous } \\
\text { craftsmen); }\end{array}$ \\
\hline $\begin{array}{l}\text { women who are responsible for the family, child rearing [5. } \\
165-175 . \\
\text { ]. }\end{array}$ \\
\hline
\end{tabular}

In management processes, the personal example of the manager is particularly noteworthy. Discipline, manners, sensitivity, vigilance, exemplary qualities of the first leader in assessing the effectiveness and scope of work, unknowingly nurture subordinates. The thinker teaches such a lesson in this regard.

For example: "... greed, hatred, envy, wrath, greed, wickedness, deceit, oppression, selfishness, malice, haste, ungratefulness, light-heartedness." "Discipline, modesty, kindness, gentleness, forgiveness, humility, generosity, patience, sincerity, gratitude, mercy, knowledge, wisdom, justice ..." it is a self-evident fact that it only benefits the reputation of the colleagues and the organization it represents [5. 183]. There is not a single minor feature of the administration that the minister and the politician have been left out of the attention of the Nizamulmulk.

For example:

Rules of organization of reception of the head;

methods of staff training;

Reasons for two non-compliance per person; 
not to involve women in public affairs;

on the specifics of responding and handling complaints;

on the order of calculation and the order of its maintenance at the required

level;

\section{Conclusion}

Nizamulmulk, who tried to establish a special direction in the administration, said, "The state is like a candle. People find their way in this light and come out of the darkness" It is natural that he quoted such verses as a description of the problems of the Seljuk rulers in governance and their efforts to find solutions to these problems.

"In every age and epoch, a man is elevated to the throne of the nation, and he is endowed with crafts, pleasing virtues", the author of these lines believes that obedience to existing laws throughout his life and activity is the main criterion of a just state, $\mathrm{He}$ also defended and supported a number of intellectuals, scholars, poets and writers.

The establishment of the Nizamiyya Madrasah of Law and Law in Baghdad in 1067 and the introduction of world-renowned scholars (Umar Khayyam, Ghazzali) to the world and the propagation of secular knowledge are proof of the exemplary activity of the thinker in the field of governance.

\section{References}

1. Independence: An Annotated Popular Science Dictionary. Tashkent: Sharq, 1998. p. 239.

2. Pharoah Abu Nasr. A city of noble people. Tashkent: Yangi asr avlodi, 2016. - pp. 238-280-284.

3. Tokhliyev B. Yusuf Khos Hajib's work "Kutadgu bilig". Tashkent: "Cholpon", 1991. p. 5.

4. Ravshanov F. National leadership: history and experience. Monograph. Tashkent: Academy, 2007. - p. 6.

5. Nizamulmulk, Siyasatnoma or Siyar ul-muluk. Tashkent: 1997. -pp. 100-183.

6. Yusuf Khos Hajib. "Kutadg'u bilig". Tashkent: Science. 1971.

7. Nizomulmulk. "Siyasatnoma". (Siyarul-muluk.). Tashkent: New Century Generation 2017.

8. Amir Temur. "Temur's rules". Tashkent: Uzbekistan.2011.

9. Doniyorov, A. K., \& Karimov, N. R. (2020). An Incomparable Book of a Great Scholar. Bulletin Social-Economic and Humanitarian Research, (6), 63-71. 